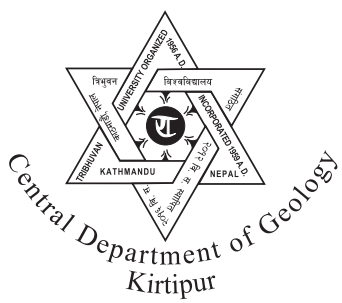

\title{
Groundwater condition of Banepa area, Central Nepal
}

\author{
*Suresh Shrestha and Suresh Das Shrestha \\ Central Department of Geology, Tribhuvan University, Kirtipur, Kathmandu, Nepal
}

\begin{abstract}
Only surface water has been distributed in the Banepa Municipality area, Central Nepal by Nepal Water Supply Corporation (NWSC) and is not sufficient as per the demand of public. A hydrogeological study was made to know the groundwater potential of the area. Banepa lies entirely in the Lesser Himalaya and constitutes consolidated phyllite and metasandstone basement rocks, and Quaternary sediment of gravel, sand and carbonaceous clay deposited in the valley. The thickness of sediment ranges from 20 to $40 \mathrm{~m}$, of which gravel, sand and clay individually approach upto 20,5 and $15 \mathrm{~m}$, respectively. Transmissivity of the aquifer varies from 0.8 to $3.15 \mathrm{~m}^{2} /$ day. Hydraulic conductivity varies from 0.022 to $0.14 \mathrm{~m} /$ day and specific capacity varies from 1.2 to 72 $\mathrm{m}^{3} / \mathrm{day} / \mathrm{m}$ in the study area. The thickness of the aquifer is low and the hydraulic properties are also not favorable to extract sufficient quantity of groundwater in Banepa area. Therefore, an alternative source of water supply should be explored to fulfill present and future water demand.
\end{abstract}

\section{INTRODUCTION}

Banepa which lies about $26 \mathrm{~km}$ east from the centre of the Kathmandu Valley, Nepal (Fig. 1), is facing acute shortage of water supply. Being a small city in terms of population, the demand for water supply is not so high. Although groundwater from shallow dug well is being used at household level, Nepal Water Supply Corporation (NWSC) responsible for municipal water supply uses only surface water. APTCOS (2001) studied prospect of groundwater in Banepa Municipality and suggested tha appropriate location and depth of drilling for construction of bore well using geophysical method. NADCO (2002) and SSCDPL (2002) drilled number of wells in Banepa. BEMP (2003) mapped rock types and soil of Banepa and analysed groundwater and surface water of the area.

*Corresponding author:

E-mail address: suresh-shrestha@hotmail.com
The present study was carried out to investigate groundwater condition and potential in the Banepa area that covers about $20 \mathrm{~km}^{2}$.

\section{METHOD AND MATERIAL}

Geological survey of the Banepa area was conducted to obtain the local geology of the study area. Water levels of dug wells were measured by using simple measuring tape. The wells were slected randomly according to availability. In total, $26 \mathrm{dug}$ wells were selected for groundwater level monitoring. The groundwater levels were measured for two seasons, i.e., pre-monsoon and monsoon. The groundwater level for pre-monsoon was measured in the first week of June 2007 and for monsoon was measured in the second week of August 2007. Lithologs of bore wells, pumping test data and water quality analysis data were collected from different drilling companies, NWSC and Banepa municipality. Analyses of available data were made to evaluate groundwater condition and potential. 


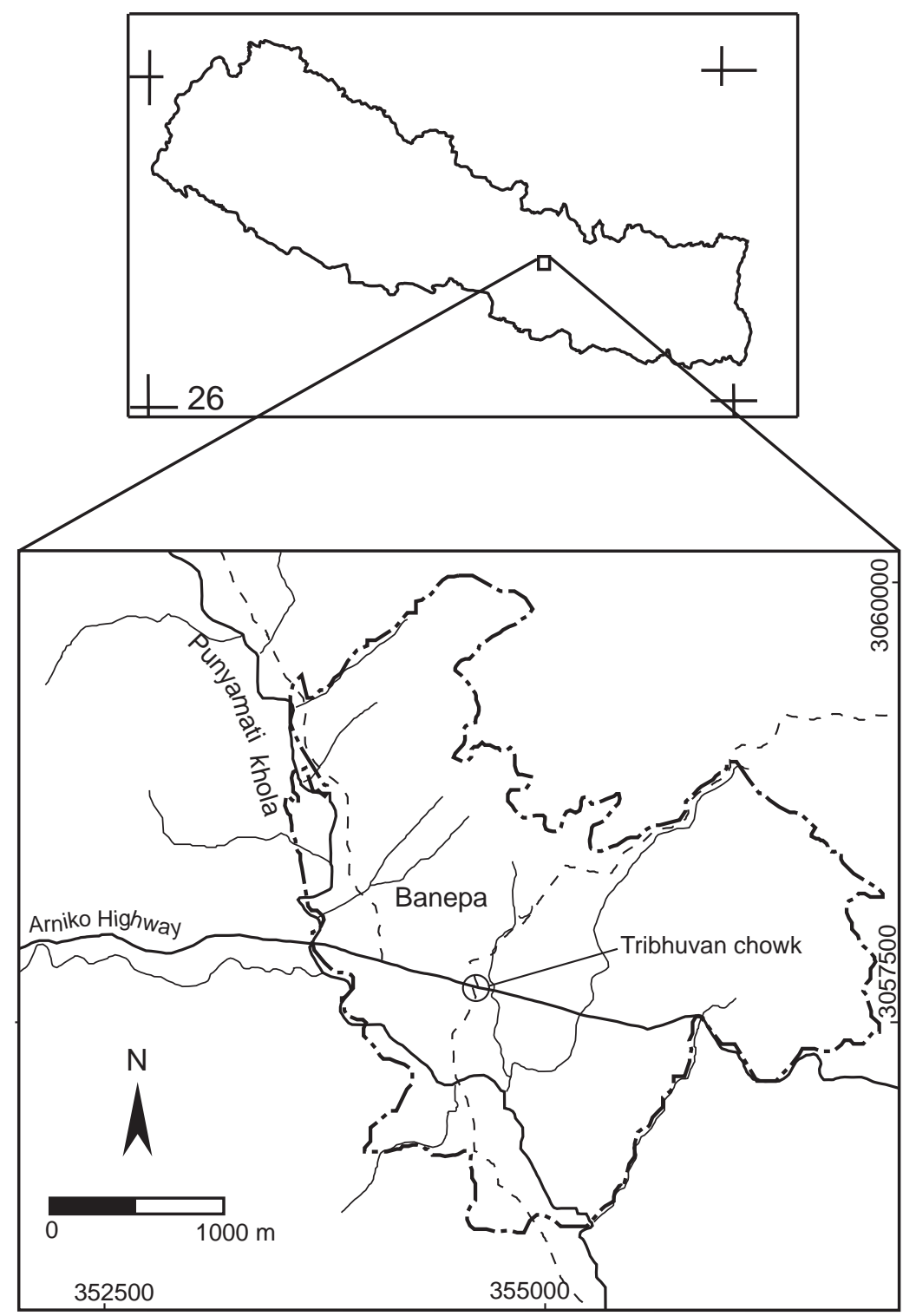

Fig. 1 Location map of the study area

\section{GEOLOGY OF STUDY AREA}

The study area is located in Banepa, Central Nepal Lesser Himalaya. Geomorphological evolution of the study area was studied by Chetri (1993). Chetri (1993) also classified landforms and drainage pattern and described weathering of rocks. The rock succession of the study area can be subdivided into consolidated basement rocks and Quaternary sediments (Figs 2 and 3). Stöcklin and Bhattarai (1981) mapped geology of the Central Nepal. Following their classification of rock units, the study area comprises rocks of the Phulchoki Group. The rocks are low-grade metasedimentary (phyllite and metasandstone) belonging to the Tistung Formation. The age of the Tistung Formation is considered to be early Cambrian according to Stocklin and Bhattarai (1981). The Quaternary sediments consists of black carbonaceous lacustrine clay deposits and alluvial fine to coarse sand and gravel. Thick black carbonaceous clay indicates lacustrine deposit (Dill et al. 2003).

Phyllites observed in the study area are of two types, one with thin parting and intercalation with metasandsotnes, and the other of thick bedded. The 


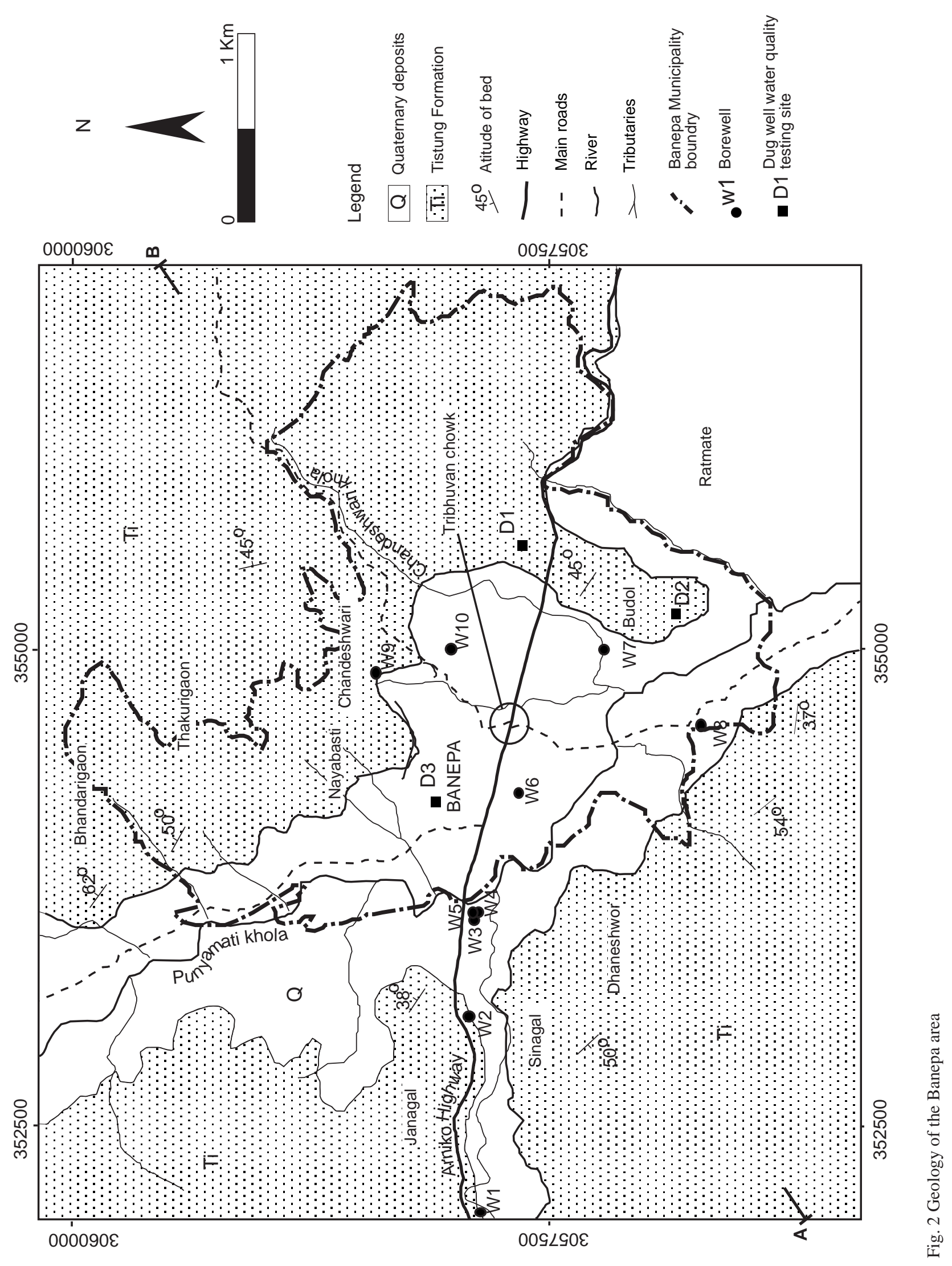




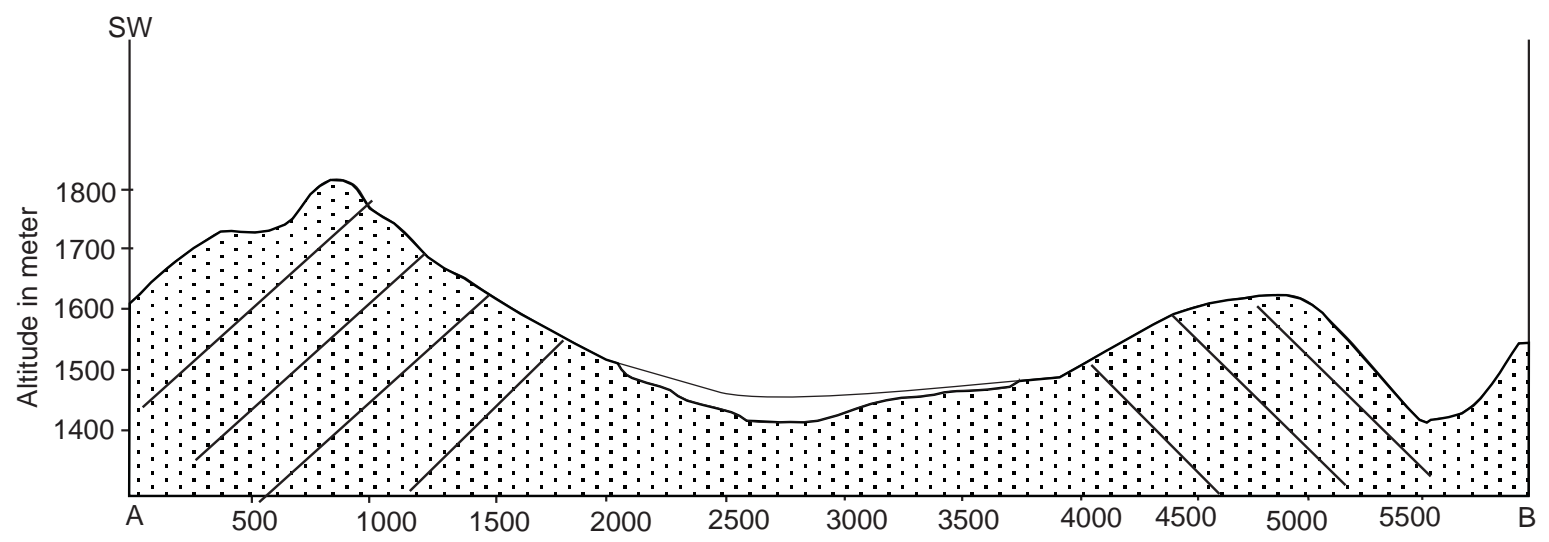

Fig. 3 Geological cross-section along A B in Fig. 2

typical phyllite beds of the Tistung Formation exposed in the north of the study area is highly weathered and grey to greenish grey in colour. The phyllites interbedded with metasandstones show several microfolding. There are also many quartz veins in phyllites.

Metasandstones observed are highly weathered. Two varieties of metasandstones were observed. The white metasandstone are quartz and feldspar rich with little mica. The attitude of bedding plane varies from $148^{\circ} / 50^{\circ} \mathrm{NE}$ to $120^{\circ} / 57^{\circ} \mathrm{SW}$ in the southern part of the study area.

The valley floor of Banepa consists of fluviolacustrine Quaternary deposit composed of gravel, sand and clay. The thickness of the Quaternary sediments varies from $10 \mathrm{~m}$ to $45 \mathrm{~m}$ from the north to the south (Fig. 3). Mostly the sediment thickness is more than $40 \mathrm{~m}$ in the southern and the central parts, but is only upto $20 \mathrm{~m}$ in the northern and the western parts. Gravel is located mainly at the bottom of the Quaternary sediment. The thickness of gravel ranges from 5 (in the NW) to $20 \mathrm{~m}$ (in the central and the southern parts). Sand with occasional gravel overlies the gravel layer, and approaches 2 to $5 \mathrm{~m}$ in thickness. Likewise alternation of fine sands and black carbonaceous and plastic clay layers are deposited above the sand. The thickness of clay deposit varies from 2 to $15 \mathrm{~m}$. There are comparatively thick layers of clay at the central and the southern portion of the Banepa area. At the top of the Quaternary deposit, there is a top soil. The overall Quaternary deposit exhibits a fining upward sequence (Figs 3 and 4) as observed from the bore hole logs after APTCOS (2002), NADCO (2002) and SSC (2002).

\section{AQUIFER FEATURES}

Graphical sections drawn from bore hole logs extending from $\mathrm{N}$ to $\mathrm{S}$ and from $\mathrm{E}$ to $\mathrm{W}$ are shown in Fig. 4 and Fig. 5, respectively. In the western part of Banepa, a confined aquifer horizon begins from 12 to $20 \mathrm{~m}$ below ground level in which 2 to $3 \mathrm{~m}$ clay layer is interbedded between the gravelly sand layers. Similarly, in the central part, the aquifer starts from $8 \mathrm{~m}$ upto $42 \mathrm{~m}$ below the ground level. The aquifer materials are sand to sandy gravel. Besides the Quaternary sediments aquifer, bedrock aquifer are also tapped in the western part of Banepa. The aquifer horizons from 20 to $60 \mathrm{~m}$ below the ground level are usually tapped.

All the aquifer parameters were calculated from the pumping test data availabe and have been listed in Table 1.

\section{Transmissivity}

Transmissivity of the Quaternary sediment aquifer 


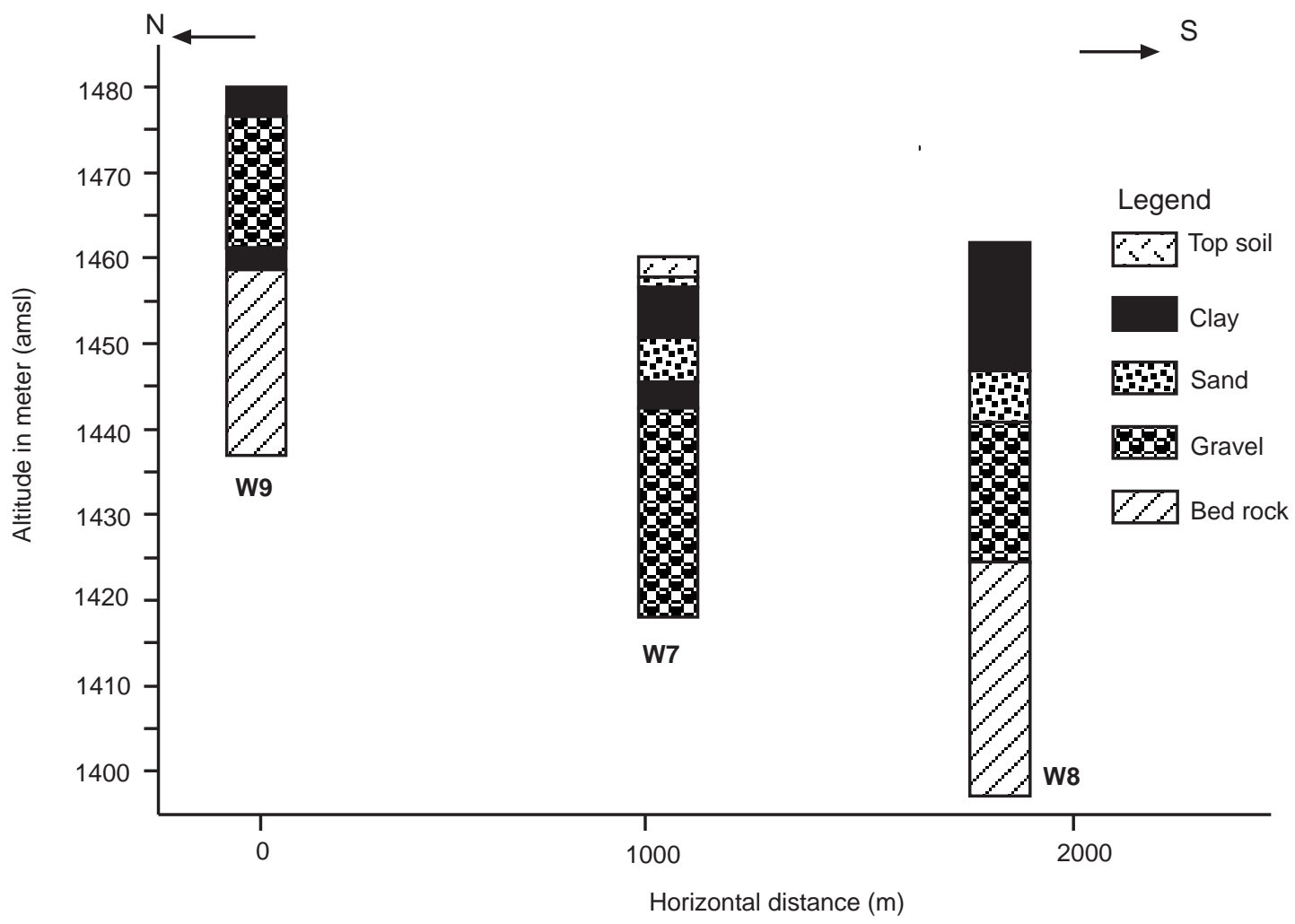

Fig. 4 Bore hole graphical log along N S line showing the aquifer materials (vertical scale exaggerated)

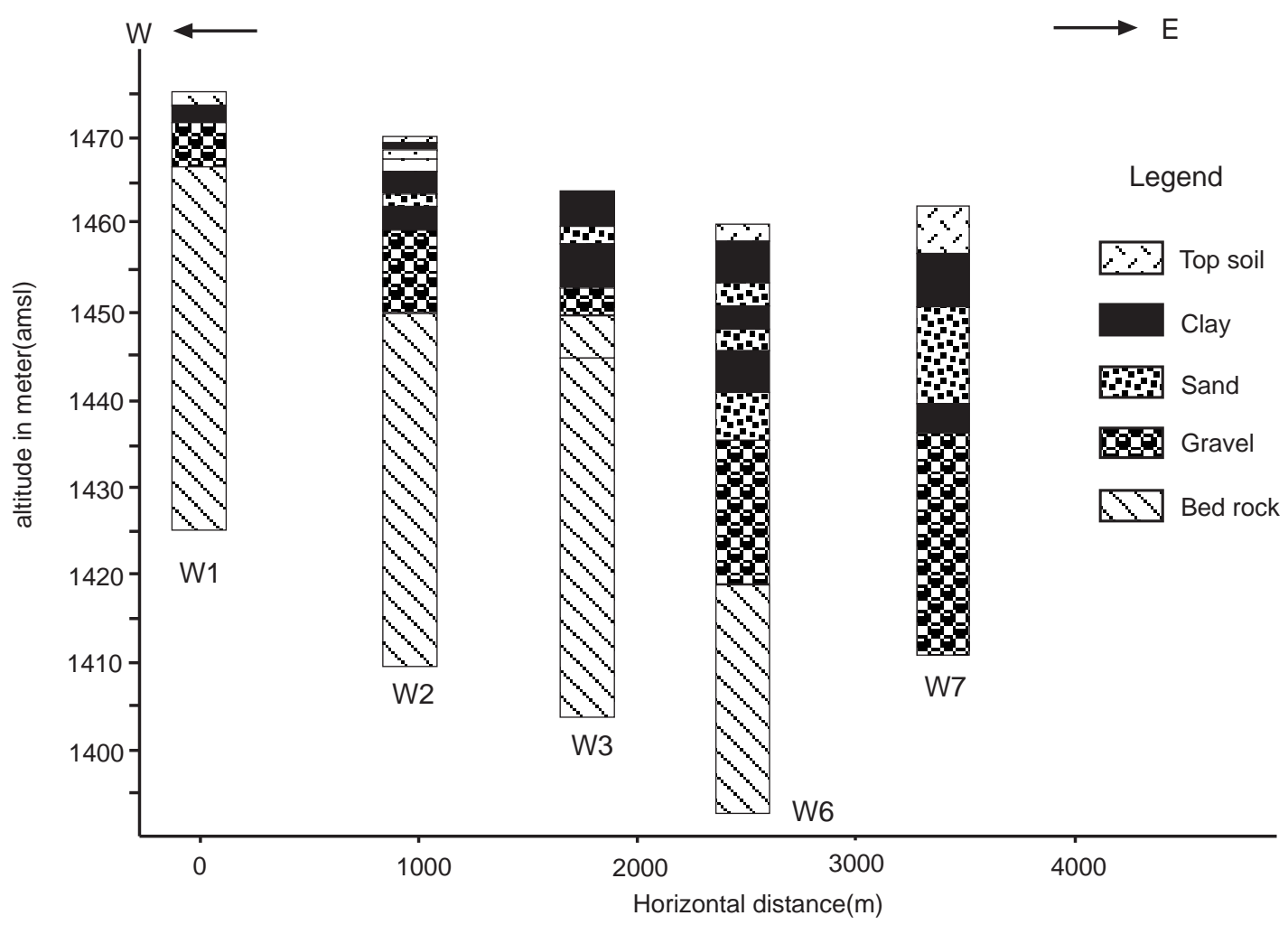

Fig. 5 Bore hole graphical log along E W line showing the aquifer materials (vertical scale exaggerated) 
Table 1: Bore well data of Banepa with hydraulic properties of the aquifer

\begin{tabular}{|c|c|c|c|c|c|c|c|c|c|c|}
\hline Well & Owner & $\begin{array}{l}\text { Bedrock } \\
\text { depth } \\
(\mathrm{m})\end{array}$ & $\begin{array}{l}\text { Screen } \\
\text { position } \\
(\mathrm{m})\end{array}$ & $\begin{array}{l}\text { Static } \\
\text { water } \\
\text { level }(\mathrm{m})\end{array}$ & $\begin{array}{l}\text { Dynamic } \\
\text { water } \\
\text { level }(\mathrm{m})\end{array}$ & $\begin{array}{l}\text { Draw } \\
\text { down } \\
(\mathrm{m})\end{array}$ & $\begin{array}{l}\text { Discharge } \\
1 / \mathrm{m}\end{array}$ & $\begin{array}{l}\text { e Transmi } \\
\text { ssivity } \\
\text { m²/day }^{2}\end{array}$ & $\begin{array}{l}\text { Hydraulic } \\
\text { conductivity } \\
\text { m/day }\end{array}$ & $\begin{array}{l}\text { Specific } \\
\text { capacity } \\
\mathrm{m}^{3} / \text { day } / \mathrm{m}\end{array}$ \\
\hline W1 & Curex Pharmatical P. L. & 8.5 & $14-15$ & 2 & 30.5 & 28.5 & 25 & - & - & 1.26 \\
\hline W2 & Dabur Nepal P. L. & 20 & $20-60$ & 1.5 & 18.5 & 17 & 70 & - & - & 5.92 \\
\hline W3 & $\begin{array}{l}\text { Himalayan Hygenic Snacks } \\
\text { and Noodles }\end{array}$ & & $\begin{array}{l}12-18 \\
30-36 \\
40-60\end{array}$ & 2.5 & 29 & 26.5 & 50 & - & - & 3 \\
\hline W4* & $\begin{array}{l}\text { Himalayan Hygenic Snacks } \\
\text { and Noodles }\end{array}$ & & $\begin{array}{l}13-18 \\
36-42 \\
48-72\end{array}$ & 5.96 & 45.6 & 39.6 & 50 & 0.8 & 0.022 & 1.8 \\
\hline W5 & $\begin{array}{l}\text { Himalayan Hygenic Snacks } \\
\text { and Noodles }\end{array}$ & & $\begin{array}{l}9-13 \\
15-16\end{array}$ & 0.5 & - & - & 112 & - & - & 6 \\
\hline W6 & Banepa Municipality & 45 & $\begin{array}{l}14-17 \\
20-38\end{array}$ & 3 & 6 & 3 & 150 & - & - & 72 \\
\hline $\mathrm{W} 7 *$ & NWSC, Ratmate & - & $21-39$ & 1.47 & 32 & 30.5 & 180 & 2.6 & 0.14 & 8.64 \\
\hline W8* & IT partk & - & & 3 & 52 & 49 & 120 & 3.16 & 0.075 & 5.2 \\
\hline W9* & Poly Technical Institute & - & $\begin{array}{l}7-13 \\
22-40\end{array}$ & 1 & 23 & 22 & 60 & 2.26 & 0.094 & 3.92 \\
\hline W10 & Sheer Memorial Hospital & 13 & - & - & - & - & - & - & - & - \\
\hline
\end{tabular}

* Wells underwent pumping tests

varies from $0.8 \mathrm{~m} 2 /$ day to $3.15 \mathrm{~m} 2 /$ day. The central and the souther parts have comparatively high transmissivity than the western and the norther parts (Table 1), but in general, the transmissivity was low as compared to that in the other place like Kathmandu.

\section{Hydraulic conductivity}

Hydraulic conductivity varied from 0.022 to 0.140 $\mathrm{m} /$ day, while cleasn gravel and sand should possess 10 to $1000 \mathrm{~m} /$ day. This indicates that gravel and sand in the aquifer material should have been mixed with fines. Actually the available litholog data do not provide details of aquifer material and only give crude information of sediment size.

\section{Specific capacity}

Specific capacity of a well, which is a well's yield per unit drawdown, expressed usually as a cubic metre per day per metre $\left(\mathrm{m}^{3} / \mathrm{day} / \mathrm{m}\right)$, varied from 1.2 to $72 \mathrm{~m} 3 / \mathrm{day} / \mathrm{m}$. The wells in the central part of the study area had higher specific capacity than in the other parts.

\section{GROUNDWATER CONDITION}

Rivers in Banepa are not perennial but are seasonal streams. For example, sufrace flow exists throughout the year in the upstream portion of the Punyamati Khola, but becomes completely dry in the downstream portion during the dry season. Therefore, the major source of water for the ancient people of Banepa was groundwater. People in old settlements of the are used groundwater for their daily need, as this is revealed by the presence of many dug wells lined by traditional bricks. But at present, people of the old city have left the tradition of using the dug wells and 
are using the water supplied by NWSC. Most of the dug wells in the old town had completely abandoned. There are only few wells which still functions. In the new settlement areas, people are still using the water from the dug wells.

The total depth of dug wells varies from 3 to 12 $\mathrm{m}$; mostly the wells are of 5 to $6 \mathrm{~m}$ deep. The water level of the dug wells varied from 1 to $10 \mathrm{~m}$ below ground level in the pre-monsoon time, whereas in the monsoon time it varied from 0.08 to $8 \mathrm{~m}$ (Shrestha 2007). The fluctuation of water level was about $2 \mathrm{~m}$ in average but upto $5 \mathrm{~m}$ was noted in the well of Nayabasti (Fig. 2). In the Budol area, one well had water level $10 \mathrm{~m}$ below ground level which had the deepest water level measured in the study area. Most of the wells in Budol were located in the residual soil. The materials found during the construction of shallow dug wells were yellowish grey to black clay, gravelly sand mixed with silt and clay nad thick fine sands. General flow of groundwater was from the north to the south (Shrestha 2007).

\section{Drinking water scarcity}

Almost all the parts of the Banepa area suffer from the water scarcity. Where people get the water from NWSC. Because of high demand and scarcity of water NWSC distributes water in alternate days only. In those places where NWSC could not provide water, people are using water from the shallow dug wells for all purpose including for drinking although the quality and quantity are not satisfactory and sufficient (Table 2). In some places like Budol, the quantity of water from one shallow well was not even sufficient to a single house during dry season. Similarly, in some places the iron content was so high that people could not use water for drinking

Table 2: Water supply by Nepal Water Supply Corporation (After BEMP (2003) and NWSC)

\begin{tabular}{llll}
\hline Date & Population & $\begin{array}{l}\text { Water } \\
\text { distributed by } \\
\text { NWSC, 1/day }\end{array}$ & 1/day/person \\
\hline 2002 & 16934 & 680,000 & 40 \\
2007 & 30,000 & 1000,000 & 33 \\
\hline
\end{tabular}

(Table 3). Infilling of surface water into the well, during rainy season is another problem. In the other season they used the same water from dug well for drinking but during the rainy season, the surface water infliltrates into the well makes the water turbid and unpotable.

BEMP (2003) conducted study on demand of water supply and status of water supply in Banepa Municipality. Banepa Municipality had 16934 population according to census of 2001. NWSC was distributing about 40 litre/day/person, while the water requirement was $135 \mathrm{litre/day/person.} \mathrm{The} \mathrm{total}$ distribution of water by NWSC during 2003 was 0.7 million letre per day (BEMP 2003). The present day population is estimated to be more than 30,000 (personal communication with Banepa Municipality). At present, water collection and distribution by NWSC amounts to abut 1 million litre per day. As in Table 2 , the water availability for per person per day has decreased but due to change in life style and socioeconomic changes, the rate of water consumption has definitely increased.

\section{Groundwater quality}

Groundwater quality varies from place to place. Some of the water from dug wells in the central part is not good enough to be used as the source of drinking water without adequate treatment. During rainy season, water becomes turbid in some of the wells due to the contamination of surface water. Water quality data of BEMP (2003) shows that the water of dug wells is not safe for drinking purpose due to higher concentration of salts (Table 3) than the criteria set by World Health Organization (WHO). Presence of coliform bacteria is also higher than the criteria of WHO. Lack of sanitation in the periphery of the sources of groundwater and lack of awareness among the people about the cause of contaminations are the major causes of the contamnation of the well. Similarly, the water qualities of some bore wells are also not favorable for drinking without treatment. The concentration of ammonia and iron is very high some wells too (Table 4).

\section{DISCUSSION}

Study of available lithologs along N-S and along E-W of bore wells (Figs 4 and 5) shows that the 
Table 3: Water quality data of bore wells of Banepa

\begin{tabular}{|c|c|c|c|c|c|c|c|c|c|c|}
\hline \multirow{2}{*}{$\begin{array}{l}\text { Serial } \\
\text { no. }\end{array}$} & \multirow[t]{2}{*}{ Parameter } & \multicolumn{4}{|c|}{ Observed values } & \multirow[b]{2}{*}{ W5 } & \multirow[b]{2}{*}{ W7 } & \multirow[b]{2}{*}{ W8 } & \multirow[t]{2}{*}{ Unit } & \multirow{2}{*}{$\begin{array}{l}\text { WHO Guidelin } \\
\text { values(1991) }\end{array}$} \\
\hline & & $* \mathrm{~W} 1$ & W2 & W3 & W4 & & & & & \\
\hline 1 & Appearance & Clear & Clear & Clear & Clear & Clear & Turbid & - & - & \\
\hline 2 & Turbidity & $<5$ & 10 & 5 & $<5$ & 6 & 41 & - & NTU & $5 \operatorname{Max}$ \\
\hline 3 & Colour & $<5$ & $<5$ & $<5$ & $<5$ & 21 & 20 & - & Hazen & \\
\hline 4 & Temperature & 14 & 17 & 12 & 25 & - & 28.7 & - & ${ }^{\circ} \mathrm{C}$ & \\
\hline 5 & $\mathrm{PH}$ & 8 & 7.7 & 7.2 & 7.2 & 7.7 & 6.4 & 6.8 & - & $6.5-8.5$ \\
\hline 6 & Electric conductivity & 240 & 164 & 180 & 230 & - & 292 & - & $\mu \mathrm{S} / \mathrm{mS} / \mathrm{cm}$ & \\
\hline 7 & Total Alkalinity $\left(\mathrm{CaCO}_{3}\right)$ & 130 & 98 & 130 & 96 & 7.6 & 132 & 8.1 & $\mathrm{mg} / \mathrm{l}$ & \\
\hline 8 & Total hardness $\left(\mathrm{CaCO}_{3}\right)$ & 116 & 82 & 110 & 64 & - & 96 & 500 & $\mathrm{mg} / \mathrm{l}$ & \\
\hline 9 & Calcium hardness & 96 & 68 & 90 & 50 & - & - & - & $\mathrm{mg} / \mathrm{l}$ & \\
\hline 10 & Magnesium hardness & 20 & 14 & 20 & 14 & - & - & - & $\mathrm{mg} / \mathrm{l}$ & \\
\hline 11 & Calcium (Ca) & 38.4 & 27.2 & 36 & 20.02 & 28 & 25 & - & $\mathrm{mg} / \mathrm{l}$ & \\
\hline 12 & Magnesium(Mg) & 4.8 & 3.4 & 4.8 & 3.4 & $<1$ & 8 & - & $\mathrm{mg} / \mathrm{l}$ & \\
\hline 13 & Total iron $(\mathrm{Fe})$ & 0.1 & 0.8 & 0.5 & 0.6 & 0.17 & 13.54 & 2.2 & $\mathrm{mg} / \mathrm{l}$ & $0.3 \operatorname{Max}$ \\
\hline 14 & Total ammonia $\left(\mathrm{NH}_{3}\right)$ & 0.05 & 0.02 & 0.02 & 0.08 & 0.15 & 3.31 & 0.02 & $\mathrm{mg} / \mathrm{l}$ & $0.05-1.5$ \\
\hline 15 & Chloride $(\mathrm{Cl})$ & 7.68 & 19.2 & 17.2 & 11.5 & 5.60 & 9.5 & 40 & $\mathrm{mg} / \mathrm{l}$ & Up to 250 \\
\hline 16 & Manganese (Mn) & 0.01 & 0.05 & - & - & 0.14 & 1.04 & 0.15 & $\mathrm{mg} / \mathrm{l}$ & Up to 0.5 \\
\hline 17 & Nitrate $\left(\mathrm{NO}_{3}\right)$ & - & - & - & - & $<0.1$ & 0.62 & 0.003 & $\mathrm{mg} / \mathrm{l}$ & Up to 10 \\
\hline
\end{tabular}

*W1 to W5 tested in Micro-Chem Laboratory, Kuleshwor, Kathmandu, Redg. No. 19126/62; W7 tested in CEMAT water lab p. Ltd Bijuli Bazar, New Baneshwar, P.O. Box:3953 W8 tested in Nepal Bureau of standards and metrology, HMG, Accredited Laboratory, P.O. Box:2967

thickness of the loose sediments vary from $15 \mathrm{~m}$ to $45 \mathrm{~m}$ different parts of Banepa. The discharge fo the wells of western part is comparatively lower than that in the central and the southern parts. THis may be due to the change in thickness of the loose aquifer material, i.e., gravel and sand, as in the central and the southern parts, the sediments are thicker than in the western and the northern parts. Similarly, the aquifer parameters, i.e., transmissivity, hydraulic conductivity and specific capacity are higher in the central and southern parts than in other parts. Therefore, the central and the southern parts have high potential of water than the other parts. But if we compare the thickness of the Quaternary sediments with other valley from, which large quantity of groundwater is being extracted, the thickness of the study area is very small as well as hydraulic parameters are not favorable for the extraction of groundwater in large quantity. Low transmissivity and hydraulic conductivity may be due to fine sediment mixed with gravel and sand which is not clear from the avilable lithologs.

Although rock aquifer has been tapped in some places, the discharge is low most probably due to intercalation of phyllite which tends to retard percolation of water. Therefore, the bedrocks of Banepa are not reliable aquifer for the extraction of groundwater.

At present the demand of water is about 4 million litres per day, considering the standsard requirement of 135 letre per person per day for the population of about 30,000 . But now NWSC is fulfilling only about 1 million litre per day. Other option might be the construction of bore wells in sufficient number to 
Table 4: Water quality data of dug wells of Banepa

\begin{tabular}{cllll}
\hline S.N. & Parameters & \multicolumn{3}{c}{ Observed values } \\
\hline 1 & PH & 6.7 & 6.7 & D2 \\
\hline 2 & Conductivity $(\mu$ mhos/cm) & 252 & 354 & 1071 \\
3 & Turbidity(NTU) & 3 & $<1$ & 20.5 \\
4 & Total Suspended Solids $(\mathrm{mg} / \mathrm{l})$ & 1 & $\mathrm{~N} . \mathrm{D}$. & 18 \\
5 & Total Hardness as $\mathrm{CaCO}_{3}(\mathrm{mg} / \mathrm{l})$ & 72 & 106 & 185 \\
6 & Total Alkalinity as $\mathrm{CaCO}_{3}(\mathrm{mg} / \mathrm{l})$ & 39.9 & 77.27 & 127.1 \\
7 & Chloride $(\mathrm{mg} / \mathrm{l})$ & 28.5 & 42.5 & 86.51 \\
8 & Ammonia $(\mathrm{mg} / \mathrm{l})$ & 0.12 & 0.15 & 0.53 \\
9 & Nitrate $(\mathrm{mg} / \mathrm{l})$ & 34.1 & 33.21 & 186.4 \\
10 & Nitrite(mg/l) & 0.14 & 0.14 & 0.35 \\
11 & Calcium(mg/l) & 20.04 & 34.47 & 32.46 \\
12 & Magnesium(mg/l) & 5.35 & 4.86 & 25.28 \\
13 & Iron(mg/l) & 0.07 & N.D. & 0.45 \\
14 & Total Coliform Count & & & \\
\hline
\end{tabular}

*D1, D2 and D3 are dug wells and shown in the Fig.2

Source: Banepa Environmental Mapping Project (BEMP), 2003

reduce the demand. For that about 46 wells will be required to extract shortage amount, i. e., 3 million litres per day, considering the average discharge of wells as $90 \mathrm{l} / \mathrm{m}$ and pumping 12 hours per day. But this may be impractical and exonomically not fesible to construct such a large number of wells in a small area. Moreover, the draw down of the wells are high (Table 1), if such a large number of wells are installed. Therefore it is suggested that the increasing demand of drinking water of Banepa might not be fulfilled by groundwater, and alternative source for drinking water should be explored.

\section{CONCLUSION}

Thickness of the aquifer material (the Quaternary valley sediment) is comparatively less than the other valley fill basin like Kathmandu. Hydraulic parameters of the aquifer like transmissivity, hydraulic conductivity and discharge are also not preferable for the extraction of sufficient quantity of groundwater.
The draw downs of almost all the wells are very high. The discharge of the rock aquifer is also not satisfactory. Similarly, the water quality of groundwater is not suitable for drinking purpose without adequate treatment. Therefore there is little potential of groundwater in Banepa as the source of water supply, and it is urgently required to explore another surce and medium of water to meet future demend.

\section{ACKNOWLEDGEMENTS}

Authors would like to thank Central Department of Geology, Tribhuvan University, Nepal for providing field instruments. Authors thank S. B. Maharjan and M. R. Pokharel for assistance in sampling and field survey. Authors are thankfull to Banepa Municipality, Nepal Water Supply Corporation, NADCO and SSCDL for providing subsurface well data, and to Nepal Bureau of Standard and Measurement, CEMAT water lab, Kathmandu, and Microchemical Lab, 
Kathmandu for providing water quality data of Banepa, Nepal.

\section{REFERENCES}

APTCOS, 2002. Prospect of groundwater in Banepa Municipality, Kavrepalanchowk. Report submitted by Appropriate Technoloty Consulting Services to Nepal Water Supply Corporation, branch office, Banepa, Nepal, $11 \mathrm{p}$.

BEMP, 2003. Banepa Environmental Mapping Report. A report submitted to NSET, 59p .

Chetri, M., 1993. Geomorphological evolution of Banepa valley. Unpublished M. Sc. dissertation submitted to the Central Department of Geology, Tribhuvan University, Nepal, 60p.

Dill, H.G., Khadka, D.R., Khanal, R., DOhramann, R.,
Melcher, F. and Busch, K., 2003. Infilling of the younger Kathmandu-Banepa intermontane basin during the later Quaternary (Lesser Himalaya, Nepal); a sedimentological study. Journal of Quaternary Science, v. 8, pp. 4160.

NADCO, 2002. Water well construction at IT park Banepa, National Drilling Co. (P) Ltd., 3p.

SSCDPL, 2002. Construction of deep tube well at Banepa Municipality. A report submitted to Nepal Water Supply Corporation, branch office, Banepa, $8 \mathrm{p}$

Shrestha, S., 2007. Hydrogeological study of Banepa area, Kavrepalanchowk District, Central Nepal. Unpublished M. Sc. dissertation submitted to the Central Department of Geology, Tribhuvan University, Nepal, 61p.

Stöcklin, J. and Bhattari, K.D., 1981. Geology of Kathmandu area and central Mahabharat range, Nepal Himalaya HMG/UNDP Mineral exploration project, Technical report Kathamandu, Nepal, 64p. 